\title{
Undercooling and nodule count in thin walled ductile iron castings
}

\author{
Pedersen, Karl Martin; Tiedje, Niels Skat
}

Published in:

International Journal of Cast Metals Research

Link to article, DOI:

$10.1179 / 136404607 \times 239816$

Publication date:

2007

Document Version

Publisher's PDF, also known as Version of record

Link back to DTU Orbit

Citation (APA):

Pedersen, K. M., \& Tiedje, N. S. (2007). Undercooling and nodule count in thin walled ductile iron castings. International Journal of Cast Metals Research, 20(3), 145-150. https://doi.org/10.1179/136404607X239816

\section{General rights}

Copyright and moral rights for the publications made accessible in the public portal are retained by the authors and/or other copyright owners and it is a condition of accessing publications that users recognise and abide by the legal requirements associated with these rights.

- Users may download and print one copy of any publication from the public portal for the purpose of private study or research.

- You may not further distribute the material or use it for any profit-making activity or commercial gain

- You may freely distribute the URL identifying the publication in the public portal

If you believe that this document breaches copyright please contact us providing details, and we will remove access to the work immediately and investigate your claim. 


\title{
Undercooling and nodule count in thin walled ductile iron castings
}

\author{
K. M. Pedersen and N. S. Tiedje*
}

Casting experiments have been performed with eutectic and hypereutectic castings with plate thicknesses from 2 to $8 \mathrm{~mm}$ involving both temperature measurements during solidification and microstructural examination afterwards. The nodule count was the same for the eutectic and hypereutectic castings in the thin plates $(\leqslant 4.3 \mathrm{~mm}$ ) while in the $8 \mathrm{~mm}$ plate the nodule count was higher in the hypereutectic than in the eutectic castings. The minimum temperature before the eutectic recalescence $\left(T_{\mathrm{min}}\right)$ was 15 to $20^{\circ} \mathrm{C}$ lower for the eutectic than for the hypereutectic castings. This is due to nucleation of graphite nodules which begins at a lower temperature in the eutectic than in the hypereutectic castings. The recalescence $\Delta T_{\text {rec }}$ was however also larger for the eutectic casting and in the thin plates the maximum temperature after recalescence $\left(T_{\max }\right)$ was the same in the eutectic and hypereutectic plates. This is because higher undercooling gives a larger driving force for the solidification process and the equal nodule counts therefore give the same $T_{\max }$. However, the higher undercooling before recalescence increases the risk for formation of carbides during the solidification. In the $8 \mathrm{~mm}$ plates, the lower nodule count in the eutectic plates also gave a lower $T_{\max }$ than in the hypereutectic castings.

Keywords: Ductile cast iron, Thin walled castings, Undercooling, Nodule counts

\section{Introduction}

Ductile cast iron has good mechanical properties, good castability and is very competitive in price compared with other materials. By optimisation using ribs and hollow sections the weight of ductile cast iron parts can be reduced and be comparable with e.g. light weight materials. ${ }^{1}$ This will however give thin sections with high cooling rates in the casting. In order to promote the nucleation of graphite and by that reduce the risk of carbides hypereutectic cast iron is normally used for thin walled casting. This does however increase the risk of graphite flotation and degenerated graphite nodules in thicker parts of the casting. ${ }^{2}$ This can give some limits in the use of high carbon equivalent for the castings. The aim of the present work is therefore to investigate solidification of thin walled castings for hypereutectic, eutectic and hypoeutectic castings involving both temperature measurements during solidification and microstructural examination afterwards.

\section{Experimental}

Ductile iron castings were produced from hypereutectic, eutectic and hypoeutectic melts in batches of $90 \mathrm{~kg}$. The chemical analyses of the castings are shown in Table 1.

Department of Manufacturing Engineering and Management, Technical University of Denmark, Produktionstorvet, Building 425, $2800 \mathrm{Kgs}$. Lyngby, Denmark

*Corresponding author, email nt@ipl.dtu.dk
The melt was superheated to $1520^{\circ} \mathrm{C}$ before being poured into a preheated ladle for magnesium treatment with a $\mathrm{Fe}-\mathrm{Si}-\mathrm{Mg}$ alloy using a tundish sandwich method. The melt for each mould was then poured into a small insulated fibre cup where it was inoculated with $0 \cdot 1-0 \cdot 2 \% \mathrm{Fe}-\mathrm{Si}$ alloy before it was poured into the mould. The temperature was measured in the fibre cup with an $\mathrm{S}$ type thermocouple and the casting temperatures are shown in Table 1.

Two different casting layouts were used in the experiments. Casting layout A (Fig. 1a) consisted of two parallel, stepped plates with thicknesses of $8,4 \cdot 3$ and $2.8 \mathrm{~mm}$. This layout was parted horizontally and the moulds were made of sodium silicate bonded sand. Casting layout B (Fig. 1b) consisted of four plates with thicknesses of $1 \cdot 5,2,3$ and $4 \mathrm{~mm}$. These castings were made in vertically parted green sand moulds on a Disamatic moulding machine. In casting layout $\mathrm{B}$, a copper chill could also be placed to obtain a chilled sample of the castings. The copper chill was used in castings $\mathrm{H}, \mathrm{K}, \mathrm{J}$ and $\mathrm{L}$.

The temperature was measured in the middle of each plate using percussion welded $\mathrm{K}$ type thermocouples with $0.2 \mathrm{~mm}$ wire. The thermocouples were placed perpendicular to the surface of the casting and a ceramic tube was used as protection material except at the measuring point. The sample rate for temperature measurement was $500 \mathrm{~Hz}$ and every 100 values were averaged to reduce noise giving a time increment of $0 \cdot 2 \mathrm{~s}$. The measured temperatures were corrected for the measurement error caused by the response time of the 


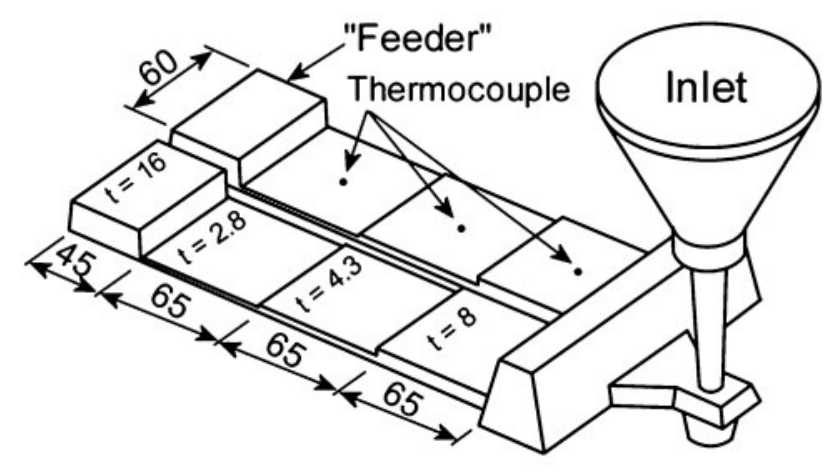

(a)

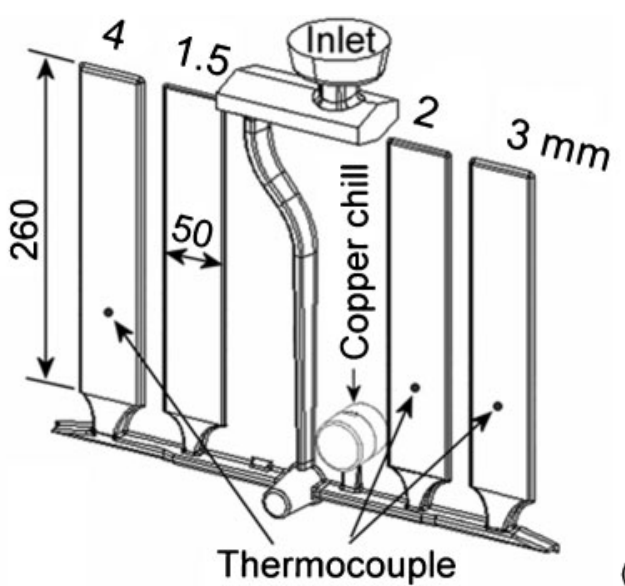

(b)

1 Casting layout a horizontal parted mould and $b$ vertical parted mould

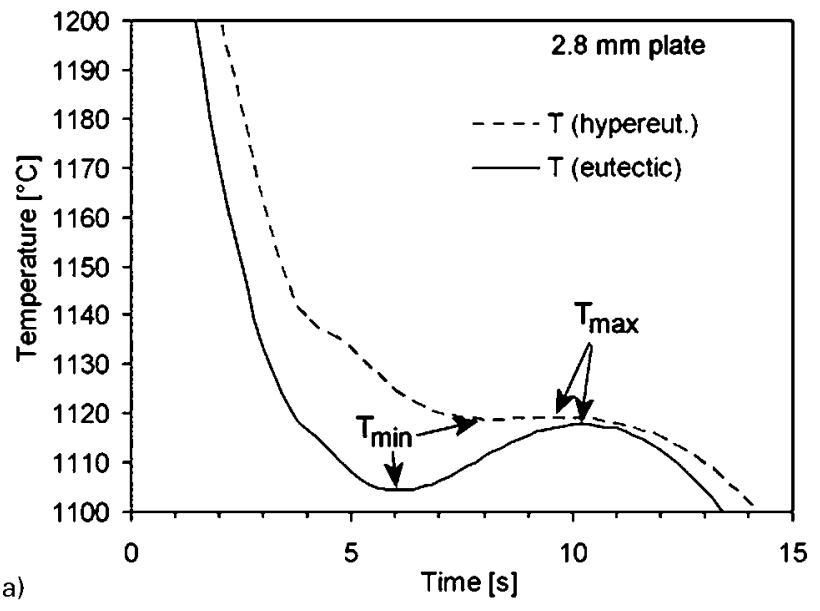

a $2.8 \mathrm{~mm}$ plate; $b 8.0 \mathrm{~mm}$ plate

2 Cooling curves from hyper-, hypo- and eutectic casting

thermocouple. $^{3-5}$ The temperature was measured in all plates except for the $1.5 \mathrm{~mm}$ plates.

Characterisation of graphite morphology and matrix microstructure was performed on cross-sections of the plates close to the thermocouples. Areas with shrinkage porosities were not used for analysing microstructure. Micrographs were taken at a magnification of $\times 156$ which gave a pixel size of $0.57 \mu \mathrm{m}$. For the chilled samples the microstructure was analysed at a magnification of $\times 250$, which gave a pixel size of $0.36 \mu \mathrm{m}$. The size of the graphite nodules was measured using the image tool Image-Pro Plus $4 \cdot 1$. The two-dimensional (2D) spatial size distribution of nodules was converted to a three-dimensional (3D) size distribution by using a finite difference method developed by Basak and

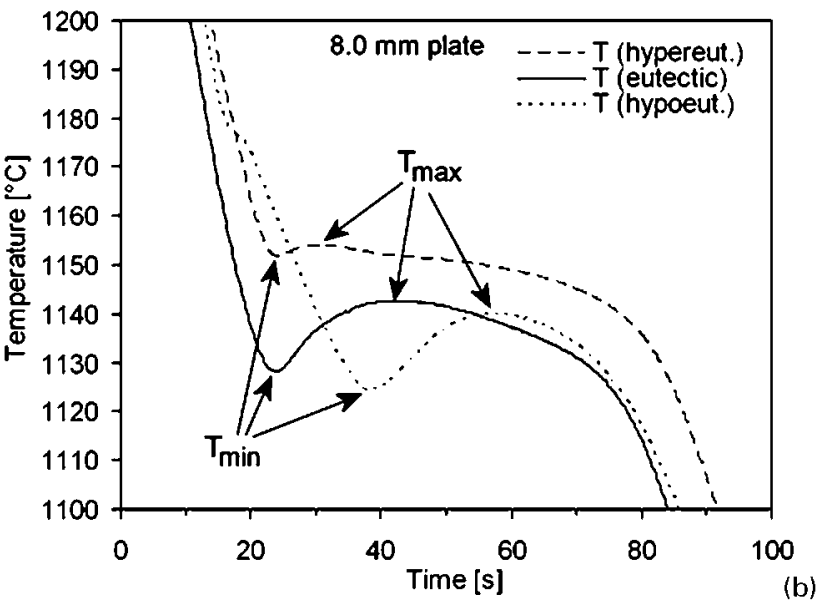

Sengupta. ${ }^{6}$ All the graphite nodules size distributions were bimodal with a minimum corresponding to a diameter in between 5 and $10 \mu \mathrm{m}$. Particles below this minimum were neglected in the nodule count. The samples were etched in a $3 \%$ nital solution to reveal ferrite, pearlite and carbides.

\section{Results}

The majority of the thin plates in the hypoeutectic castings had a high content of carbides, so only the $8 \mathrm{~mm}$ plates of the hypoeutectic castings will be dealt with here. Examples of cooling curves for 2.8 and $8.0 \mathrm{~mm}$ plates are shown in Fig. 2. The temperature $T_{\min }$ is defined as the minimum temperature before the

Table 1 Chemical analysis of castings (CEV $=\% \mathrm{C}+0.28 \times \% \mathrm{Si})$ and casting temperature

\begin{tabular}{|c|c|c|c|c|c|c|c|c|c|}
\hline & Casting & $\mathrm{C}$ & $\mathrm{Si}$ & $\mathrm{Mn}$ & $\mathbf{P}$ & $\mathrm{S}$ & $\mathrm{Mg}$ & CEV & Casting temperature, ${ }^{\circ} \mathrm{C}$ \\
\hline \multirow[t]{3}{*}{ Hypereutectic } & $E$ & $3 \cdot 70$ & $2 \cdot 75$ & 0.044 & 0.025 & 0.010 & 0.037 & $4 \cdot 47$ & 1340 \\
\hline & $\mathrm{H}$ & 3.90 & 2.69 & 0.045 & 0.021 & 0.010 & 0.033 & 4.65 & 1370 \\
\hline & $\mathrm{K}$ & $4 \cdot 15$ & $2 \cdot 11$ & 0.040 & 0.024 & 0.013 & 0.039 & $4 \cdot 74$ & 1360 \\
\hline \multirow[t]{3}{*}{ Eutectic } & $\mathrm{F}$ & 3.51 & $2 \cdot 70$ & 0.044 & 0.026 & 0.010 & 0.030 & $4 \cdot 27$ & 1350 \\
\hline & $J$ & 3.57 & $2 \cdot 64$ & 0.041 & 0.022 & 0.011 & 0.028 & $4 \cdot 31$ & 1350 \\
\hline & $\mathrm{L}$ & 3.65 & $2 \cdot 10$ & 0.042 & 0.025 & 0.013 & 0.038 & $4 \cdot 24$ & 1350 \\
\hline \multirow[t]{2}{*}{ Hypoeutectic } & $G$ & $3 \cdot 26$ & 2.67 & 0.043 & 0.020 & 0.008 & 0.030 & $4 \cdot 01$ & 1390 \\
\hline & $\mathrm{M}$ & $3 \cdot 40$ & 2.03 & 0.045 & 0.025 & 0.008 & 0.027 & 3.97 & 1350 \\
\hline
\end{tabular}

*For all castings: Ni 0.017; $\mathrm{Cr} \sim 0.032 ; \mathrm{Al} \sim 0.01$; Co 0.025; Cu 0.007; Ti 0.02; $\mathrm{V} \sim 0.03 ; \mathrm{W}<0.007 ; \mathrm{Mo}, \mathrm{Nb}, \mathrm{As}, \mathrm{Sn}$ and $\mathrm{Pb}<0.005$; $\mathrm{Zr}, \mathrm{Zn}$ and $\mathrm{B}<0 \cdot 001$. 

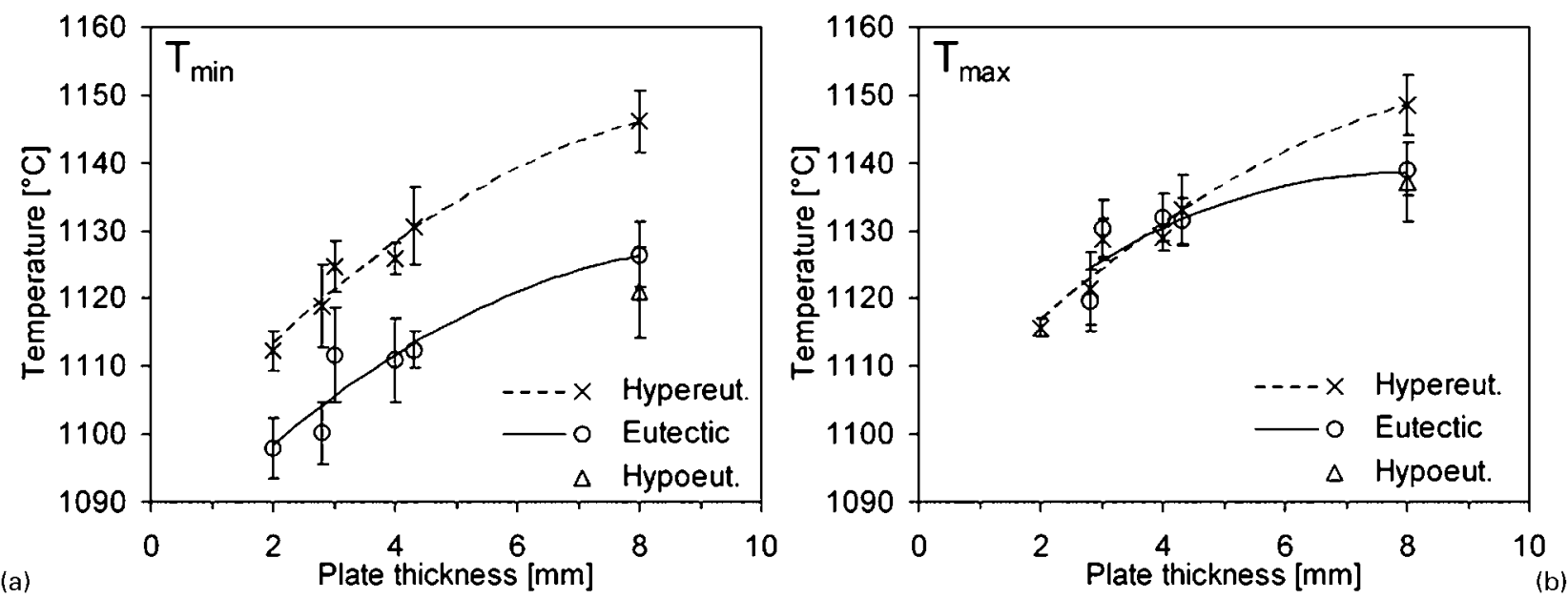

3 a minimum temperature before and $b$ maximum temperature after eutectic recalescence versus plate thickness

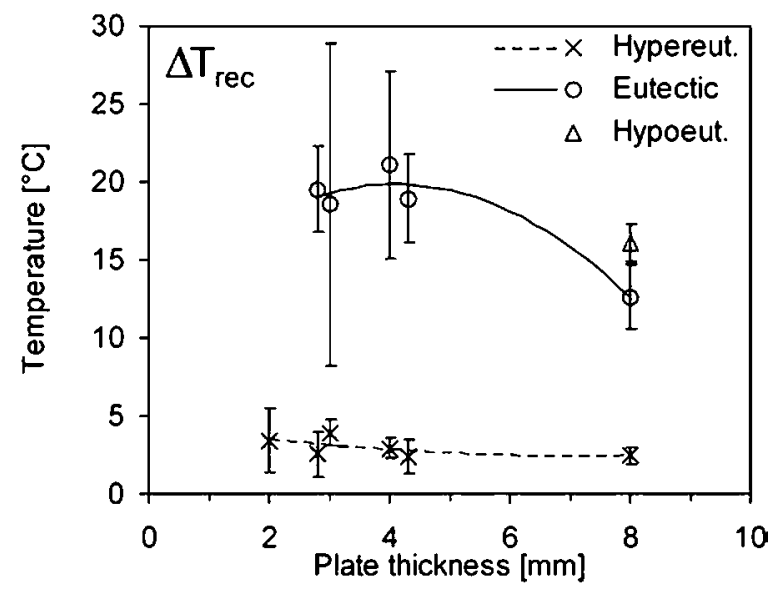

castings is about $10^{\circ} \mathrm{C}$ lower than that in the hypereutectic castings (Fig. 3b).

There is a higher recalescence in the eutectic than in the hypereutectic castings (Fig. 4). While the hypereutectic castings have a recalescence less than $5^{\circ} \mathrm{C}$, the recalescence in the eutectic castings are typically in between 15 and $20^{\circ} \mathrm{C}$. The temperatures of the hypoeutectic $8 \mathrm{~mm}$ plates were very close to corresponding eutectic castings (see Figs. 2-4). The cooling curves of the hypoeutectic castings also show the nucleation of primary austenite at $\sim 1180^{\circ} \mathrm{C}$ (see Fig. $2 b$ ).

The average graphite nodule count for the different plate thicknesses is shown in Fig. $5 a$. The nodule count increases with decreasing plate thickness. The nodule count is similar for the eutectic and hypereutectic castings except for the $8 \mathrm{~mm}$ plate where the hypereutectic castings had a higher nodule count. The nodule count in the hypoeutectic $8 \mathrm{~mm}$ plates was a little lower than in the eutectic castings.

In the hypereutectic castings, there were also a group of large nodules (see Fig. 5b). The number of large nodules increased with decreasing plate thickness. In the eutectic and hypoeutectic castings, there were very few, if any, large nodules, as shown in Fig. 5b. The size of the large graphite nodules in the hypereutectic castings was larger than that of the graphite nodules in the eutectic castings. similar for the eutectic and hypereutectic castings, except for the for $8 \mathrm{~mm}$ plate, where the $T_{\max }$ for the eutectic

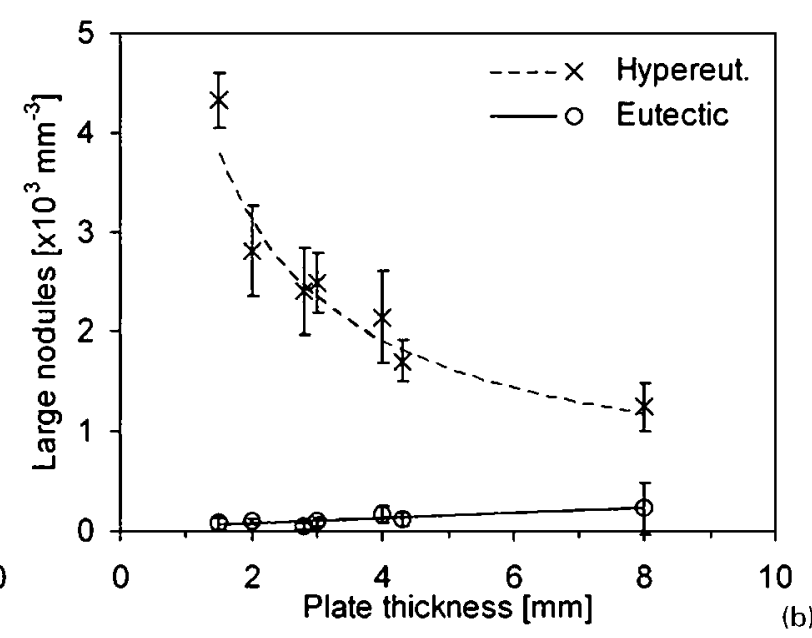

(a)

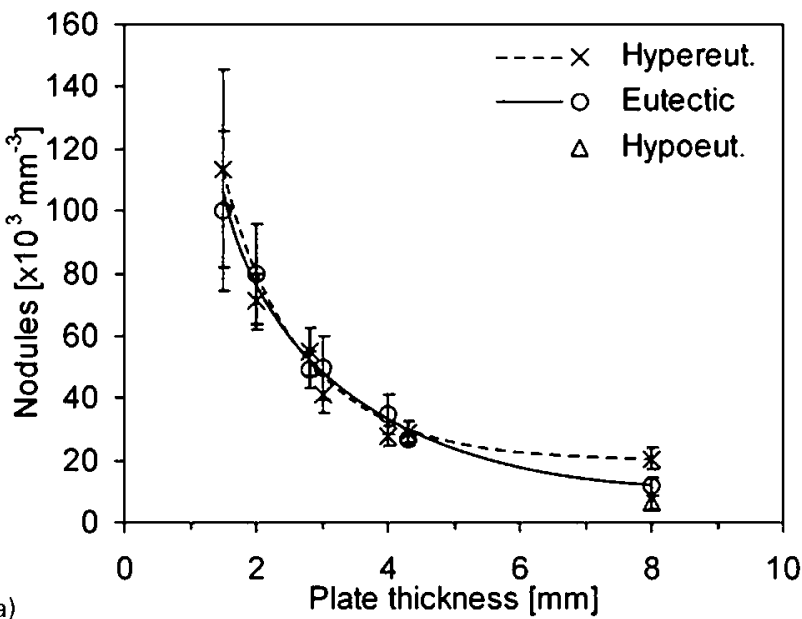

5 a graphite nodule count and $b$ number of large graphite nodule versus plate thickness 


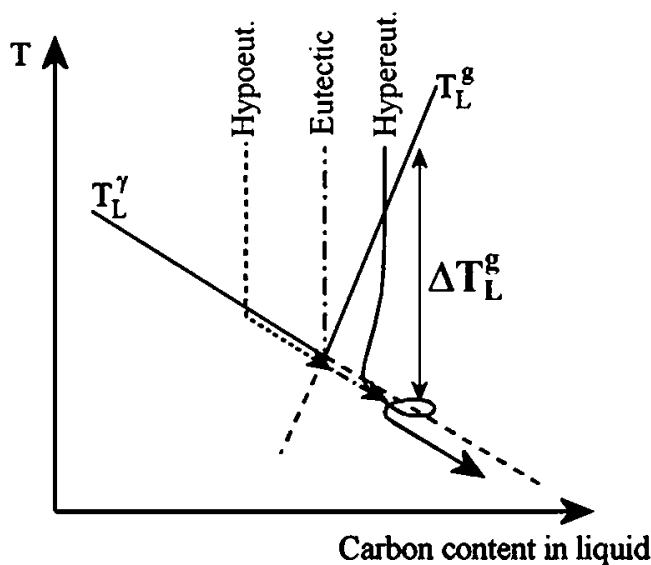

6 Solidification path and undercooling in relation to phase diagram

In the chilled samples, the main part solidified as 'white' eutectic, i.e. as austenite + carbide eutectic. In the hypereutectic castings $(\mathrm{H}$ and $\mathrm{K})$, there were however also some graphite nodules, with $\sim 30000$ nodules $\mathrm{mm}^{-3}$ in casting $\mathrm{H}$ and $\sim 17000$ nodules $\mathrm{mm}^{-3}$ in casting $\mathrm{K}$. In the eutectic castings ( $\mathrm{J}$ and $\mathrm{L}$ ), there were very few graphite nodules found only in the centre of the chilled samples.

\section{Numerical simulation}

The numerical simulation was based on the solidification model by Lesoult, Castro and Lacaze. ${ }^{7,8}$ The solidification model has been incorporated in a transient 1D description taking into account thermal gradients and heat transfer coefficient. ${ }^{9}$ The solidification model is based on the assumption that during the solidification the carbon content in the liquid follows the austenite liquidus line or the extrapolation of that (see Fig. 6). The nucleation law used in the model is a continuous nucleation law where the number of nucleated graphite nodules, $\Delta N_{\mathrm{i}}$, in time step $i$, is governed by the undercooling, $\Delta T_{\mathrm{L}}{ }^{\mathrm{g}}$, with respect to the graphite liquidus ${ }^{7}$

$$
\begin{aligned}
& \Delta N_{\mathrm{i}}=A_{\mathrm{n}}\left(\Delta T_{\mathrm{L}}^{\mathrm{g}}\right)^{\mathrm{n}-1} f^{\mathrm{l}} \frac{\mathrm{d}\left(\Delta T_{\mathrm{L}}^{\mathrm{g}}\right)}{\mathrm{d} t} \mathrm{~d} t \quad \text { when } \frac{\mathrm{d}\left(\Delta T_{\mathrm{L}}^{\mathrm{g}}\right)}{\mathrm{d} t}>0 ; \\
& \Delta N_{\mathrm{i}}=0 \quad \text { when } \frac{\mathrm{d}\left(\Delta T_{\mathrm{L}}^{\mathrm{g}}\right)}{\mathrm{d} t}<0
\end{aligned}
$$

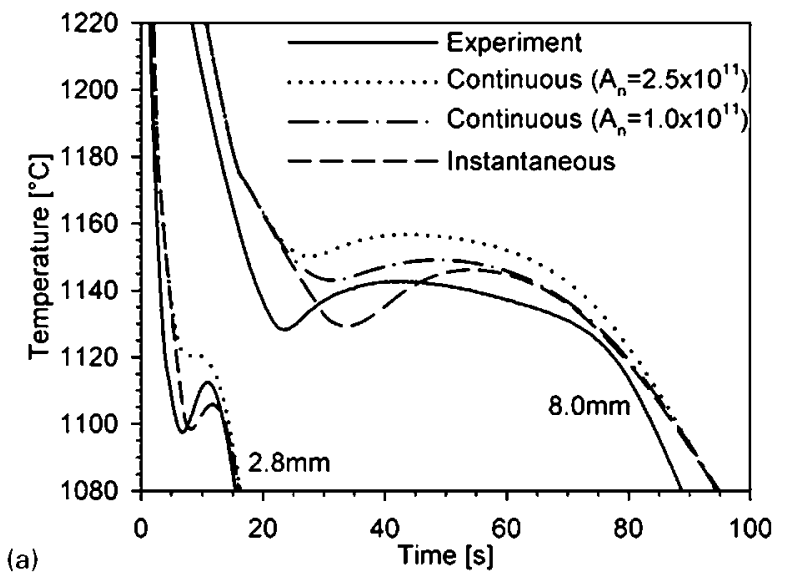

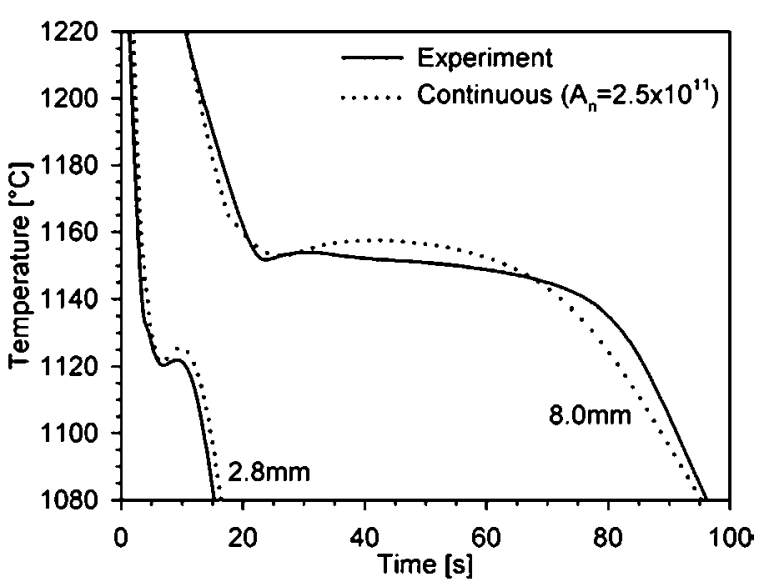

7 Experimental and simulated cooling curves for hypereutectic castings

where $n$ and $A_{\mathrm{n}}$ are nucleation constants and $f^{1}$ is the liquid fraction.

Concerning the hypereutectic castings there was good agreement between the experimental and simulated cooling curves (see Fig. 7) and also the concerning the nodule count when using the nucleation parameters $n=1$ and $A_{\mathrm{n}}=2 \cdot 5 \times 10^{11}{ }^{\circ} \mathrm{C}^{-1} \mathrm{~m}^{-3}$.

Using the same nucleation parameters for the eutectic casting, the nodule count for the thin plates was in agreement with the experiments, but the temperature was too high during solidification (see the cooling curve for the $2.8 \mathrm{~mm}$ plate in Fig. $8 a$ ). For the $8 \mathrm{~mm}$ plates, both the temperature (see Fig. 8) and the nodule count was too high during the solidification. Using $A_{\mathrm{n}}=$ $1 \cdot 0 \times 10^{11}{ }^{\circ} \mathrm{C}^{-1} \mathrm{~m}^{-3}$ the nodule count was in agreement with the experiments but the temperature, especially the $T_{\text {min }}$, was still too high (see Fig. 8).

As the temperatures were too high in the simulations for the eutectic and hypoeutectic castings instantaneous nucleation was used instead where the graphite nodules were nucleated at a specified time. The time and the nodule count for the instantaneous nucleation are showed in Table 2. The temperatures and time for start of nucleation using the continuous nucleation law are also shown in Table 2 for comparison. Using the instantaneous nucleation law, the $T_{\min }$ is in close agreement with the experimental results (see Fig. 8). Furthermore,

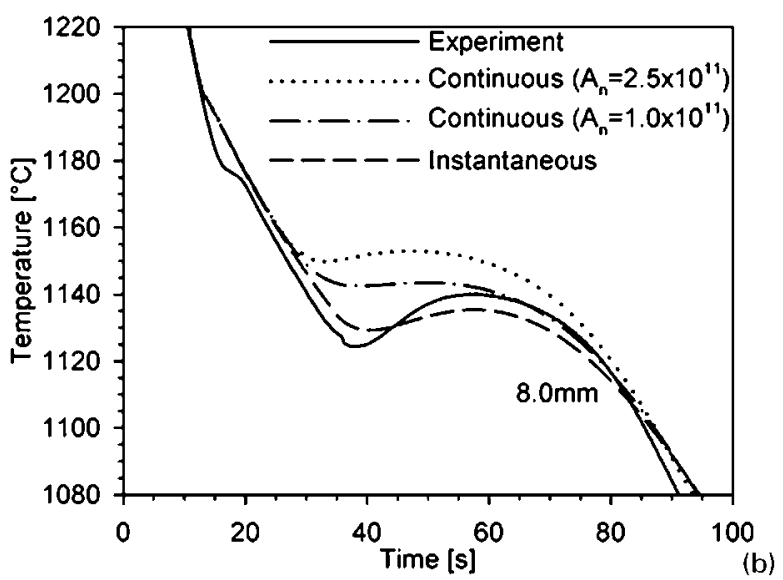

8 Experimental and simulated cooling curves for $a$ eutectic and $b$ hypoeutectic castings For the simulated cooling curves both continuous and instantaneous nucleation laws have been used. 
Table 2 Time and temperature for start of nucleation of graphite nodules in simulation

\begin{tabular}{|c|c|c|c|c|c|}
\hline \multirow[b]{2}{*}{ Casting } & \multicolumn{2}{|c|}{ Continuous (for both $A_{n}$ ) } & \multicolumn{3}{|c|}{ Instantaneous } \\
\hline & Time, s & Temperature, ${ }^{\circ} \mathrm{C}$ & Time, s & Temperature, ${ }^{\circ} \mathrm{C}$ & Nodule count, $\mathrm{mm}^{-3}$ \\
\hline Eutectic $2.8 \mathrm{~mm}$ & $3 \cdot 4$ & 1166 & $7 \cdot 0$ & 1104 & 55000 \\
\hline Eutectic $8.0 \mathrm{~mm}$ & $19 \cdot 1$ & 1166 & $30 \cdot 0$ & 1133 & 10000 \\
\hline Hypoeutectic $8.0 \mathrm{~mm}$ & $23 \cdot 4$ & 1166 & $35 \cdot 0$ & 1134 & 8200 \\
\hline
\end{tabular}

the recalescence also becomes larger, especially for the $2 \cdot 8 \mathrm{~mm}$ plate (see Fig. $8 a$ ).

\section{Discussion}

In the hypereutectic casting, the solidification will start with nucleation of primary graphite nodules (Fig. 6). The large graphite nodules found in the hypereutectic casting (see Fig. $5 b$ ), are probably primary graphite nodules. In the chilled samples, there were many graphite nodules in the hypereutectic samples and almost none in the eutectic samples. The graphite nodules in the hypereutectic chilled samples can therefore be assumed to be primary graphite nodules.

As the growth of primary graphite nodules is governed by diffusion, ${ }^{10}$ increasing cooling rates (decreasing the plate thickness) will increase the number of primary graphite nodules.

The assumption in the numerical model that the carbon content in the liquid will follow the austenite liquidus line in the phase diagram is reasonable since the graphite nodules will be surrounded very quickly by an austenite shell during solidification. ${ }^{11}$ This, however, gives some problems in the numerical modelling for hypereutectic, eutectic and hypoeutectic casting with the same nucleation law. As soon as the eutectic solidification has started all three castings will follow the same path in the phase diagram (see Fig. 6). Due to equation (1), a similar undercooling (similar $T_{\min }$ ) should give a similar nodule count except from the difference in fraction of liquid. $f^{1}$ is however close to 1 for the eutectic and about 0.8 for the hypoeutectic casting when the nucleation starts, so the difference is very small. The $T_{\min }$ is however 15 to $20^{\circ} \mathrm{C}$ lower in the eutectic and hypoeutectic than in the hypereutectic castings. The difference can be explained because, in the hypereutectic castings, the nucleation of graphite nodules starts at a higher temperature. This can serve to preinoculate the melt, so that a lot of graphite nodules are ready to grow (note the relative high nodule count in the chilled samples). Only the most favourable nodules will grow during the primary solidification, but as soon as the austenite liquidus line is reached the remaining of the nodules can start to grow. In the hypoeutectic and eutectic castings, the nucleation of graphite can start when the eutectic solidification starts. Due to the delay in the nucleation of graphite the undercooling will become larger in these types of casting.

The lower $T_{\min }$ in the eutectic casting could be because austenite also has to be nucleated. However, in the hypoeutectic casting austenite has been nucleated at a higher temperature, so this cannot be the explanation for the lower $T_{\min }$. Hence it seems that the nucleation of graphite is the limiting factor and not nucleation of austenite.

When the graphite nodules have been nucleated the remaining solidification is governed by diffusion of carbon through the austenite shell. As larger undercooling (=lower $T_{\min }$ ) will increase the driving force for growth of graphite and austenite it will also give a larger recalescence as seen in the present experiments.

The lower $T_{\min }$ in the eutectic and hypoeutectic castings increases the risk of formation of carbides during the solidification in comparison to the hypereutectic castings. There was actually higher carbide content in the thin plates in the eutectic and hypoeutectic castings than in the hypereutectic.

\section{Conclusion}

In thin walled castings, the eutectic alloys have higher undercooling (lower $T_{\min }$ ) but similar nodule count compared with hypereutectic castings. The difference is because that nucleation of graphite may take some time. As the nucleation of graphite starts at higher temperature in the hypereutectic casting than in the eutectic and hypoeutectic castings, the undercooling will be lower for the hypereutectic castings.

Simultaneous nucleation of graphite and austenite could account for the lower $T_{\min }$ in the eutectic casting but experiments with hypoeutectic castings show that this does not have an influence on the $T_{\min }$.

Numerical simulations confirm that there is a delay in nucleation of graphite in eutectic and hypoeutectic castings.

\section{Appendix}

The parameters for the numerical simulations are similar to those used in Ref. 9 except for the parameter taking into account the impingement of eutectic spheres during solidification. This has been taken from Ref. 12 as $\Phi=\left(1-f^{\mathrm{s}}\right)^{\mathrm{f}^{\mathrm{s}}}$ instead of $\Phi=\left(1-f^{\mathrm{s}}\right)$, where $f^{\mathrm{s}}$ is the solid fraction.

\section{Acknowledgements}

This work has partly been financed by Technical University of Denmark and partly by the Danish Research Council for Technology and Production Sciences, which are greatly acknowledged.

Based on a presentation at SP07, the 5th Decennial Conference on Solidification Processing, organised by the University of Sheffield, UK on 23-25 July 2007.

\section{References}

1. P. Larsen: 'Iron melt flow in thin walled sections cast in vertically parted green sand moulds', $\mathrm{PhD}$ thesis, Technical University of Denmark, Denmark, 2004.

2. A. Alagarsamy: Ductile iron handbook; 1992, Des Plaines, IL, American Foundrymen's Society, Inc.

3. K. M. Pedersen: 'Solidification and microstructure of thin walled ductile cast iron', PhD thesis, Technical University of Denmark, Denmark, 2006.

4. K. M. Pedersen and N. Tiedje: Measurement, 'Temperature measurement during solidification of thin wall ductile cast iron. 
Part 2: Numerical simulations', in press, DOI: 10.1016/j. measurement.2007.05.003.

5. K. M. Pedersen and N. S. Tiedje: Int. J. Cast Met. Res., in press, DOI: $10.1179 / 136404607$ X226838.

6. C. B. Basak and A. K.Sengupta: Scr. Mater., 2004, 51, 255-260.

7. G. Lesoult, M. Castro and J. Lacaze: Acta Mater., 1998, 46, 983-995.

8. J. Lacaze, M. Castro and G. Lesoult: Acta Mater., 1998, 46, 997-1010.
9. K. M. Pedersen, J. Hattel and N. Tiedje: Acta Mater., 2006, 54, 5103-5114.

10. F. J. Bradley: Scr. Metall. Mater., 1992, 26, 443-448.

11. S.-E. Wetterfall, H. Fredriksson and M. Hillert: J. Iron Steel Inst., 1972, 210, 323-333.

12. S. Chang, D. Shangguan and D. M.Stefanescu: Metall. Trans. A, 1992, 23A, 1333-1346 